\section{Positive association between MET allele (BDNF Val66Met polymorphism) and obsessive- compulsive disorder}

\section{Associação entre o alelo MET (polimorfismo BDNF Val66Met) e o transtorno obsessivo-compulsivo}

\begin{abstract}
Dear Editor,
Brain-derived neurotrophic factor (BDNF) is a member of the neurotrophin superfamilies, which is involved in cell survival, neuronal differentiation, synaptic efficiency and neuronal plasticity. ${ }^{1-3}$ Neurochemical and behavioral analysis have revealed that a partial impairment in BDNF expression causes physiological disturbances in central serotonergic neurons in early adulthood, eventually leading to the structural deterioration of such neurons in advanced age. ${ }^{1}$
\end{abstract}

Obsessive-compulsive disorder (OCD) is a debilitating neuropsychiatric condition. ${ }^{2-5}$ Considering that the serotonin system plays an important role in the pathogenesis of OCD, the $\mathrm{BDNF}$ gene is an interesting candidate gene for OCD.,5

BDNF Val66Met is a polymorphism that has been widely investigated in psychiatric disorders. The Met allele of the BDNF Val66Met polymorphism is associated with reduced BDNF activity and harm avoidance, and it has been suggested that it may be associated with depression, schizophrenia, bipolar disorder and OCD, although findings have been inconsistent. ${ }^{1-3}$

We sought to investigate this association in a sample of 127 Caucasian patients with OCD born in Brazil and 127 matched healthy controls. The study was approved by the Ethics Committee of the Hospital das Clínicas of the Universidade Federal de Minas Gerais and all participants were required to sign informed consent forms.

Blood samples were collected and DNA samples were obtained by the high salt method. Genotyping was performed using a made-toorder TaqMan genotyping assay. Genotyping was performed in a Mx3005P QPCR System using an allelic discrimination mode. Differences in genotype frequency were calculated by the $\mathrm{x}^{2}$ test. Any differences between groups were tested with the Student's $t$ test. Tests were two-tailed and results significant when $\mathrm{p} \leq 0.05$.

No difference in the BDNF genotype distribution was observed between OCD patients and controls: OCD patients, [Met/ Met 11 (8.66\%), Met/Val 33 (25.98\%), Val/Val 83 (25.35\%)]; controls, [Met/Met 8 (6.29\%), Met/Val 21 (16.53\%), Val/Val 98 (77.16\%)]. The genotypic distributions were in Hardy-Weinberg equilibrium ( $\mathrm{p}>0.05$ ).

When subjects were classified as carriers of either one or two copies of the Met allele or as homozygous Val carriers, an association between Met allele and OCD was observed. An additional statistical analysis using other genotypic combinations (Met/Val and $\mathrm{Val} / \mathrm{Val}$ ) was performed but led to no associations. Finally, the allele frequency demonstrated an important association between Met allele and OCD (Table 1).

In this study, we observed that the BDNF Met allele may possibly play a role in OCD patients. Considering that this study has several methodological limitations, including a small sample size and the fact that no analysis of clinical features such as age of OCD onset, gender, factor analysis-derived symptom dimensions and comorbidity with other psychiatric disorders was performed, one must be careful when generalizing results. ${ }^{2,3}$ Moreover, OCD is a spectrum disorder with multiple genes involved, each of which contributing only a small fraction to the overall risk. ${ }^{2-5}$

The importance of homogeneous patient groups is exemplified by recent reports that have demonstrated the association between Met allele and the early onset of OCD in males, similarly to the association between the Val66Val genotype and the Val allele in males and OCD patients with sexual/religious obsessions. Furthermore, Met66Met genotype has been previously associated to mild OCD in female patients. ${ }^{2,3}$

The use of endophenotypes and additional clinical data to further differentiate patient groups would greatly increase the number of specific candidate genes, although this would also require a much larger sample size. ${ }^{4}$

Table 1 - One or two copies of the MET allele versus homozygous VAL carriers

\begin{tabular}{|c|c|c|c|c|c|}
\hline \multirow[t]{2}{*}{ Cases and controls } & \multicolumn{2}{|c|}{ Genotypes } & \multirow[t]{2}{*}{$\mathbf{p}$} & \multirow[t]{2}{*}{ OR } & \multirow[t]{2}{*}{$95 \% \mathrm{Cl}$} \\
\hline & Val/Val & Val/Met + Met/Met & & & \\
\hline Controls & $98(77.16 \%)$ & $29(22.83 \%)$ & & & $103<O R<311$ \\
\hline OCD patients & $83(65.33 \%)$ & $44(34.64 \%)$ & 0.03 & 1.19 & $1.03<0 R<3.11$ \\
\hline \multirow[t]{2}{*}{ Cases and controls } & \multicolumn{2}{|c|}{ Alleles } & $\mathbf{p}$ & OR & $95 \% \mathrm{Cl}$ \\
\hline & Met & Val & & & \\
\hline Controls & $37(14.56 \%)$ & $217(85.43 \%)$ & $<001$ & 395 & $291<O R<536$ \\
\hline OCD patients & $55(21.65 \%)$ & $199(78.34 \%)$ & & & \\
\hline
\end{tabular}


Felipe Filardi da Rocha

Pharmacology and Molecular Biochemistry Program, Universidade Federal de Minas Gerais (UFMG), Belo Horizonte, MG, Brazil

Leandro Malloy-Diniz, Naira Vassalo Lage Pharmacology and Molecular Biochemistry Program, Universidade Federal de Minas Gerais (UFMG), Belo Horizonte, MG, Brazil Neuroscience Program, Universidade Federal de Minas Gerais (UFMG), Belo Horizonte, MG, Brazil
Humberto Corrêa

Pharmacology and Molecular Biochemistry Program, Universidade Federal de Minas Gerais (UFMG), Belo

Horizonte, MG, Brazil

Department of Mental Health, Faculty of Medicine, Universidade Federal de Minas Gerais (UFMG), Belo Horizonte, MG, Brazil

\section{Disclosures}

\begin{tabular}{|c|c|c|c|c|c|c|c|}
\hline $\begin{array}{l}\text { Writing group } \\
\text { member }\end{array}$ & Employment & $\begin{array}{l}\text { Research } \\
\text { grant }^{1}\end{array}$ & $\begin{array}{l}\text { Other research grant } \\
\text { or medical continuous } \\
\text { education }^{2}\end{array}$ & $\begin{array}{l}\text { Speaker's } \\
\text { honoraria }\end{array}$ & $\begin{array}{l}\text { Ownership } \\
\text { interest }\end{array}$ & $\begin{array}{l}\text { Consultant/ } \\
\text { Advisory } \\
\text { board }\end{array}$ & Other ${ }^{3}$ \\
\hline $\begin{array}{l}\text { Felipe Filardi da } \\
\text { Rocha }\end{array}$ & $\begin{array}{c}\text { UFMG } \\
\text { IMES/UNIVAÇO }\end{array}$ & $\mathrm{CNPq}^{*}$ & - & - & - & - & - \\
\hline $\begin{array}{l}\text { Leandro Malloy- } \\
\text { Diniz }\end{array}$ & UFMG & $\mathrm{CNPq}^{* * *}$ & - & - & - & - & - \\
\hline $\begin{array}{l}\text { Naira Vassalo } \\
\text { Lage }\end{array}$ & UFMG & $\mathrm{CNPq}^{*}$ & - & - & - & - & - \\
\hline Humberto Corrêa & UFMG & $\begin{array}{c}\text { CNPq }^{* * *} \\
\text { FAPEMIG }^{* * *}\end{array}$ & - & - & - & - & - \\
\hline \multicolumn{8}{|c|}{$\begin{array}{l}\text { *Modest } \\
\text { ** Significant } \\
\text { ** Significant: Amounts given to the author's institution or to a colleague for research in which the author has participation, not directly to the } \\
\text { author. } \\
\text { Note: UFMG = Universidade Federal de Minas Gerais; IMES/UNIVAÇO = Instituto Metropolitano de Ensino Superior, Universidade Vale do Aço; } \\
\text { CNPq = Conselho Nacional de Desenvolvimento Científico e Tecnológico; FAPEMIG = Fundação de Amparo à Pesquisa do Estado de Minas } \\
\text { Gerais. } \\
\text { For more information, see Instructions for Authors. }\end{array}$} \\
\hline
\end{tabular}

References

1. Deltheil T, Guiard BP, Cerdan J, David DJ, Tanaka KF, Repérant C, Guilloux JP, Coudoré F, Hen R, Gardier AM. Behavioral and serotonergic consequences of decreasing or increasing hippocampus brain-derived neurotrophic factor protein levels in mice. Neuropharmacology. 2008;55(6):1006-14.

2. Katerberg H, Lochner C, Cath DC, de Jonge P, Bochdanovits Z, MoolmanSmook JC, Hemmings SM, Carey PD, Stein DJ, Sondervan D, Boer JA, van Balkom AJ, Polman A, Heutink P. The role of the brain-derived neurotrophic factor (BDNF) val66met variant in the phenotypic expression of obsessive-compulsive disorder (OCD). Am J Med Genet B Neuropsychiatr Genet. 2009;150B(8):1050-62.
3. Hemmings SM, Kinnear CJ, Van der Merwe L, Lochner C, Corfield VA, Moolman-Smook JC, Stein DJ. Investigating the role of the brain-derived neurotrophic factor (BDNF) val66met variant in obsessive-compulsive disorder (OCD). World J Biol Psychiatry. 2008;9(2):126-34.

4. da Rocha FF, Malloy-Diniz L, Lage NV, Romano-Silva MA, de Marco LA, Correa $\mathrm{H}$. Decision-making impairment is related to serotonin transporter promoter polymorphism in a sample of patients with obsessivecompulsive disorder. Behav Brain Res. 2008;195(1):159-63.

5. da Rocha FF, Marco LA, Romano-Silva MA, Corrêa H. Obsessive-compulsive disorder and 5-HTTLPR. Rev Bras Psiquiatr. 2009;31(3):287-8. 